\title{
Bir Üniversite Hastanesine Gönderilen İdrar Kültürlerinde Üreyen İzolatların Dağılımı ve Antimikrobiyal Duyarlılık Profilinin İncelenmesi
}

The Evaluation of The Distribution and Antimicrobial Susceptibility Profile of Strains İsolated From Urine Specimens at A University Hospital

\author{
Merve Çilburunoğlu ${ }^{1}$, Özlem Kirişci ${ }^{1}$, Hacer Yerlikaya ${ }^{1}$, Hacer Uğurlü ${ }^{1}$, \\ Murat Aral ${ }^{1}$, Gürkan Muratdağ $1^{2}$ \\ ${ }^{1}$ Sütçü Imam Üniversitesi Tip Fakültesi Tibbi Mikrobiyoloji Anabilim Dal, Kahramanmaraş \\ ${ }^{2}$ Sakarya Üniversitesi Tip Fakültesi, Aile Hekimliği A.D, Sakarya \\ Yazı̧̧a Adresi / Correspondence: \\ Gürkan Muratdağ1 \\ Sakarya Üniversitesi Tip Fakültesi, Aile Hekimliği A.D, Sakarya Adres:Korucuk Mah SAUTF Dekanlik Bi冈nasi \\ T: +905330946333 E-mail : drgm54@gmail.com \\ Geliş Tarihi / Received : 30.09.2020 Kabul Tarihi / Accepted : 21.11.2020 \\ Orcid : \\ Merve Çilburunoğlu https://orcid.org/0000-0001-8627-7366 \\ Özlem Kirișci https://orcid.org/0000-0003-4784-8183 \\ Hacer Yerlikaya https://orcid.org/0000-0002-6347-5527 \\ Hacer Uğurlu https://orcid.org/0000-0001-6126-5502 \\ Murat Aral https://orcid.org/0000-0002-3576-4380 \\ Gürkan Muratdağı https://orcid.org/0000-0002-9629-3973 \\ ( Sakarya Tip Dergisi / Sakarya Med J 2020, 10(4):677-683 ) DOI: 10.31832/smj.802643
}

$\ddot{\mathrm{O} z}$

Amaç Bu çalışmada Sütçü İmam Üniversitesi Tip Fakültesỉnde idrar örneklerinden izole edilen bakteriler ve bu bakterilerin antibiyotik direnç durumlarını belirlemeyi amaçladık.

Gereç ve Ocak 2018-Ocak 2019 tarihleri arasında Kahramanmaraș Sütçü İmam Üniversitesi Tip Fakültesi Tibbi Mikrobiyoloji Laboratuvarına gönderilen 2447 orta akım idrar örneği

Yöntem çalıșmaya alındı. Üreyen bakterilerin tanımlanması ve antibiyotik duyarlılık testleri konvansiyonel ve otomatize sistemlerle (Phoenix BD, USA) çalıșıldı. Antibiyogram verileri EUCAST (European Committee on Antimicrobial Susceptibility Testing) önerileri doğrultusunda değerlendirildi.

Bulgular En stk izole edilen bakteriler E. coli 1323 (\%54,10), Klebsiella spp. 427 (\%17,40), E. faecalis 164 (\%6,70), E. faecium 117 (\%4,80), Pseudomonas spp. 92 (\%3,80), S. agalactiae 82 (\%3,30), Enterobacter spp. 64 (\%2,60), A. baumannii 48 (\%2), Proteus spp. 47 (\%1,90), S. aureus $29(\% 1,20)$, B. cephacia 24 (\%1), Citrobacter spp. 12 (\%0,50), M. morganii $11(\% 0,40)$, S. marcescens $7(\% 0,30)$ idi. E. coli için en düșük direnç amikasin (\%0.60), Klebsiella spp. için en düșük direnç imipeneme (\%9) karșı bulundu. P. aeruginosa, Enterobacter spp. ve A. baumanii izolatlarında kolistin direnci sırasıyla; \%5,10, \%1,50 ve \%2,10 idi. E. faecalis ve E. faecium için direnç oranları sırasılla; vankomisin $\% 1,80$ ve $\% 16,70$; teikoplanin $\% 1,80$ ve $\% 19,10$; linezolid $\% 1,20$ ve $\% 2,60$ olarak saptand. S. aureus'ta oksasilin direnci $\% 51,90$ olarak saptandı. S.agalactiae'de penisilin direnci saptanmadi.

Sonuç İdrar yolu enfeksiyon etkenlerinin antibiyotik direnç oranları merkezlere göre değișiklik göstermektedir. Bu yüzden her merkez kendi bölgesindeki enfeksiyon etkeni izolatların dağılımını ve antibiyotik direnç profilini belirlemeli ve tedavi protokollerini bu sonuçlara göre düzenlemelidir.

Anahtar İdrar yolu enfeksiyonu; tedavi; antibakteriyel ajanlar; bakteri

Kelimeler

Abstract

Objective In this study we aimed to determined the antibiotic resistance pattern of bacteria isolated from urinary tract infections in Kahramanmaras Sutcu Imam University, Faculty of Medicine.

Materials From January 2018 to 2019, 2447 of clean catch mid-stream urine samples which refered to Microbiology Department, College of Medicine, Kahramanmaras Sutcu Imam University were and methods studied. Identification and antibiotic susceptibility tests of relevant growing izolate were done by conventional and otomated system (Phoenix BD, USA ). Antibiogram data were based on EUCAST standards (European Committee on Antimicrobial Susceptibility Testing).

Results The most common paqthogens were E. coli 1323 (54,10\%), Klebsiella spp. 427 (17,40\%), E. faecalis 164 (6,70\%), E. faecium 117 (4,80\%), Pseudomonas spp. 92 (3,80\%), S. agalactiae 82 (3,30\%), Enterobacter spp. 64 (2,60), A. baumannii 48 (2\%), Proteus spp. 47 (1,90\%), S. aureus 29 (1,20\%), B. cephacia 24 (1\%), Citrobacter spp. 12 (0,50\%), M. morganii 11 (0,40\%), S. marcescens $7(0,30 \%)$ respectively. The lower resistance rates for E. coli and Klebsiella spp. were to amikacin 0,60\%, and imipenem 9\% respectively. Among pathogens P. aeruginosa, Enterobacter spp. and A. baumanii colistin resistance rates were $5,10 \%, 1,50 \%$ and $2,10 \%$ respectively. The resistance rates of E. faecalis and E. faecium for vancomicin, teikoplanin, and linezolid were found to be $(1,80 \% ; 16,70 \%),(1,80 \% ; 19,10 \%)$ and $(1,80 \% ; 19,10 \%)$ respectively. Oksasilin resistant rate for S.aureus were $51,90 \%$. Penicilin resistance for S.agalactiae were not found.

Conclusion Pathogens of urinary tract infections and their antibiotic resistance rates are vary from center to center. For this reason; every center has to asses their treatment protocols depending on their pathogens and resistant rate profile.

Keywords Urinary tract infection; treatment; anti-bacterial agents; bacteria 


\section{GIIRIŞ}

İdrar yolu enfeksiyonları (IYYE) piyüri ve klinik semptomlar eşliğinde böbrek, toplayıcı sistem ve mesanede inflamasyonun varlığı olarak tanımlanır. ${ }^{1}$ Önemli miktarda mali yüke neden olan İYE ülkemizde ve dünyada hem yatan hem de ayaktan tedavi gören hastalarda en sık görülen enfeksiyon hastalıklarının başında gelmektetir. ${ }^{2}$ Dünyada yılda 150 milyon civarında atak görülmekte ve altı milyar dolar harcama yapilmaktadır. ${ }^{3}$ IYE asemptomatik bakteriüriden, hayatı tehdit edebilecek ciddi enfeksiyonlara kadar geniş bir yelpazede görülebilmekte ve önemli bir morbidite nedeni olarak karşımıza çıkmaktadır. ${ }^{4}$ Bu enfeksiyonlarda en sik görülen mikroorganizmalar gram negatif bakteriler olup bunların arasında özellikle de Escherichia coli' etken olarak sık görülmektedir. Daha az olarak ise Proteus spp., Klebsiella spp., Enterobacter spp., Serratia spp. ve Pseudomonas aeruginosa etken olarak tespit edilmektedir. ${ }^{5,6}$ Üretral mukoza dışında normal üriner sistem, mikroorganizmaların kolonizasyonuna dirençlidir ve büyük bir kısmını hızlı bir şekilde uzaklaştıırı. Bu durum; hızlı idrar akımı, idrarın düşük $\mathrm{pH}$ düzeyi ve antibakteriyel etkisi, yüksek üre konsantrasyonu, idrar proteinleri gibi çeşitli savunma mekanizmalarının varlığı ile gerçekleștirilir. Diğer taraftan üropatojenler sahip oldukları virülans faktörleri sayesinde üriner sisteme kolonize olma ve hastalık oluşturma kapasitelerini artırırlar. ${ }^{7}$ Gelişmiş ülkelerde IYYE tedavisinde kullanılan antibiyotikler toplamda reçete edilen antibiyotiklerin yaklaşık \%15'ini oluşturmaktadır. IYYE'lerin tedavisinde antibiyotikler sıklıkla ampirik olarak başlanmaktadır. Trimetoprim-sülfametoksazol (TMPSXT), siprofloksasin ve beta-laktamlar tedavide en sık kullanılan ajanlardandır. Ancak ampirik olarak başlanan antibiyotiklere karşı da giderek artan oranda direnç geliştiği bildirilmektedir. Artan bu antimikrobiyal direnç profili ampirik antibiyotik seçiminde önemli bir sorun oluşturmakta ve tedavi başarı oranlarını düşürmektedir. ${ }^{4}$ Tedavisine ampirik olarak başlanılan toplum kökenli idrar yolu enfeksiyonlarında, tedaviye cevapsızlık durumlarında ya da tekrarlayan nitelikteki enfeksiyon durumlarında idrar kültürü ve antibiyotik duyarlılık yöntemlerine başvurul- maktadır. Tedavide kullanılacak ideal antibiyotiğin belirlenebilmesi için düzenli olarak antibiyotik direnç durumu izlenmelidir. ${ }^{9}$ Hastaneler ve hatta klinikler arasında bile farklı antimikrobiyal direnç oranları görülebileceği göz önüne alındığında her merkezin kendi antibiyotik direnç profillerini düzenli olarak değerlendirmesi, antimikrobiyal politikaların belirlenmesine katkı sağlayacaktır. ${ }^{4} \mathrm{Bu}$ çalışmamızda Kahramanmaraş Sütçü İmam Üniversitesi Tip Fakültesi'nde idrar örneklerinden en sık izole edilen bakteriler ve bu bakterilerin antibiyotik direnç durumlar1nı belirlemeyi amaçladık.

\section{GEREÇ ve YÖNTEMLER}

Çalışmamız kesitsel tipte tanımlayıcı bir çalışma olup Sakarya Üniversitesi Tip Fakültesi Etik Kurulundan onam alınmıştır (Etik kurul onam sayı: 71522473/050.01.04/476, Tarih: 04.09.2020).

Ocak 2018-Ocak 2019 tarihleri arasında Kahramanmaraş Sütçü İmam Üniversitesi Tip Fakültesi Tibbi Mikrobiyoloji Laboratuvarı́na gönderilen 2447 orta akım idrar örneği çalışmaya alındı ve bulgular retrospektif olarak incelendi. Örnekler 0,01 ml'lik standart öze kullanılarak \%5 koyun kanlı agar ve Eosin Metilen Blue (EMB) agara kantitatif yöntemle ekildi. Etüvde 35-37 0C'de, 24-48 saat aerop koşullarda inkübe edildi. $104 \mathrm{CFU} / \mathrm{ml}$ ve üzerinde bir veya iki çeşit mikroorganizmanın ürediği kültürler çalışmaya alındı. Üreyen bakterilerin tanımlanması ve antibiyotik duyarlılık testleri konvansiyonel ve otomatize sistemlerle (Phoenix BD, USA) çalışıldı. Antibiyogram verileri EUCAST (European Committee on Antimicrobial Susceptibility Testing) önerileri doğrultusunda değerlendirildi.

Veriler SPSS 25.0 (IBM SPSS Statistics 25 software (Armonk, NY: IBM Corp.)) paket programıyla analiz edilmiştir. Kategorik değişkenlerin tanımlanmasında sayı (n) ve yüzde (\%) kullanılmıştır.

\section{BULGULAR}

Çalışmamızda ayaktan hastalardan $1387(\% 56,70)$ ve ya- 
tan hastalardan $1060(\% 43,30)$ olmak üzere toplam 2447 örnekten izole edilen bakteriler incelendi. Buna göre en s1k izole edilen bakteriler E. coli 1323 (\%54,10), Klebsiella spp. $427(\% 17,40)$, E. faecalis $164(\% 6,70)$, E. faecium $117(\% 4,80)$, Pseudomonas spp. $92(\% 3,80)$, S. agalactiae 82 (\%3,30), Enterobacter spp. 64 (\%2,60), A. baumannii 48 (\%20), Proteus spp. 47 (\%1,90), S. aureus 29 (\%1,20), B. cephacia 24 (\%10), Citrobacter spp. $12(\% 0,50)$, M. morganii $11(\% 0,40)$, S. marcescens $7(\% 0,30)$ idi. ( Tablo 1$)$

\begin{tabular}{|l|c|c|c|c|c|c|}
\hline \multirow{2}{*}{ Tablo 1. İdrar örneklerinden izole edilen bakterilerin dağllımı } \\
\hline & \multicolumn{2}{|c|}{ Ayaktan } & \multicolumn{2}{|c|}{ Yatan } & \multicolumn{2}{c|}{ Toplam } \\
\hline & \multicolumn{2}{|c|}{$\mathrm{n}(\%)$} & \multicolumn{2}{|c|}{$\mathrm{n}(\%)$} & \multicolumn{2}{|c|}{$\mathrm{n}(\%)$} \\
\hline E.coli & 837 & $(60,40)$ & 486 & $(46)$ & 1323 & $(54,10)$ \\
\hline Klebsiella spp. & 233 & $(16,80)$ & 194 & $(18,30)$ & 427 & $(17,40)$ \\
\hline E. faecalis & 76 & $(5,50)$ & 88 & $(8,30)$ & 164 & $(6,70)$ \\
\hline E. faecium & 13 & $(0,90)$ & 104 & $(9,80)$ & 117 & $(4,80)$ \\
\hline Pseudomonas spp. & 26 & $(1,80)$ & 66 & $(6,20)$ & 92 & $(3,80)$ \\
\hline S. agalactiae & 69 & $(5)$ & 13 & $(1,20)$ & 82 & $(3,30)$ \\
\hline Enterobacter spp. & 42 & $(3)$ & 22 & $(2,10)$ & 64 & $(2,60)$ \\
\hline A.baumannii & 19 & $(1,40)$ & 29 & $(2,70)$ & 48 & $(2)$ \\
\hline Proteus spp. & 27 & $(1,90)$ & 20 & $(1,80)$ & 47 & $(1,90)$ \\
\hline S.aureus & 16 & $(1,20)$ & 13 & $(1,20)$ & 29 & $(1,20)$ \\
\hline B.cephacia & 11 & $(0,80)$ & 13 & $(1,20)$ & 24 & $(1)$ \\
\hline Citrobacter spp. & 8 & $(0,60)$ & 4 & $(0,40)$ & 12 & $(0,50)$ \\
\hline M. morganii & 6 & $(0,40)$ & 5 & $(0,50)$ & 11 & $(0,40)$ \\
\hline S. marcescens & 4 & $(0,30)$ & 3 & $(0,30)$ & 7 & $(0,30)$ \\
\hline Toplam & 1387 & $(100)$ & 1060 & $(100)$ & 2447 & $(100)$ \\
\hline
\end{tabular}

Ayaktan ve yatan hastalarda en sık izole edilen ilk iki bakteri sıralaması E. coli ve Klebsiella spp. idi. Ayaktan hastalarda üçüncü sırayı E. faecalis alırken yatan hastalarda E. faecium ald1. Pseudomonas spp. $(\% 1,80)$ ve A.baumanii $(\% 1,40)$ ayaktan hastalarda da etken olarak saptandı. (Tablo 1 )

Çalışmamızda ilk sırada izole edilen E. coli için en düşük direnç amikasin $(\% 0,60)$, imipenem $(\% 1,60)$, meropenem $(\% 2,40)$ ve fosfomisine $(\% 4,20)$ karşı bulunurken; en yüksek direnç ampisilin $(\% 75,80)$, amoksisilin-klavulonat $(\% 55,70)$, seftriakson $(\% 49,20)$ ve trimetoprim-sulfametaksazole (\%49) karşı bulundu. İkinci sırada izole edi- len Klebsiella spp. için en düşük direnç imipenem (\%9), amikasin $(\% 10,20)$, meropenem $(\% 12,40)$ ve fosfomisine $(\% 23,80)$ karşı bulunurken en yüksek direnç ampisilin (\%100), amoksisilin-klavulonat $(\% 63,90)$, seftriakson $(\% 61,20)$ ve sefepime $(\% 57,80)$ karşı bulundu. P. aeruginosa, Enterobacter spp. ve A. baumanii izolatlarında kolistin direnci sırasıyla; \% 5,10, \%1,50 ve \% 2,10 idi. Gram negafif bakterilerin antibiyotik direnç oranları Tablo 2'de gösterilmiştir. Çalışmamızda üçüncü ve dördüncü sırada izole edilen E. faecalis ve E. faecium idi. E. faecalis ve E. faecium için direnç oranları sırasıyla ampisilin için \%1,80 ve \%93,90; siprofloksasin için \%32,70 ve \%85,60; vankomisin için $\% 1,80$ ve $\% 16,70$; teikoplanin için $\% 1,80$ ve $\% 19,10$; linezolid için \% 1,20 ve \%2,60 olup yüksek düzey streptomisin direnci $\% 41,50$ ve $\% 72,80$; yüksek düzey gentamisin direnci $\% 23,10$ ve $\% 52,70$ oranlarında saptandı. S. aureus' ta penisilin direnci $\% 96$, oksasilin direnci \%51,90 olarak saptandi. S.agalactiae'de penisilin direnci saptanmazken; $\% 47$ oranında eritromisin ve \%21 oranında klindamisin direnci saptandı. Gram pozitif bakterilerin antibiyotik direnç oranları Tablo 3’te gösterilmiştir.

\section{TARTIŞMA}

Üriner sistem enfeksiyonları (ÜSE) tüm dünyada en sık görülen enfeksiyon olup en sık izole edilen etken ise Escherichia colidir. ${ }^{10}$ Yaptığımız çalışmada da en sık izole edilen bakteri E. coli $(\% 54,10)$ olarak saptandi.

Kinolonlar ülkemizdeki toplum kaynaklı ÜSE’lerde birinci ve ikinci basamak tedavisinde kullanılan antibiyotiklerin başında geldiğinden son yıllarda bu grup antibiyotiklere karşı oluşan direnç hızla artmıştır. ${ }^{11}$ Saraçoğlu ve ark. yaptıkları çalışmada E. coli için 2008-2010 yılları arasında siprofloksasin direnç oranını \%46 gibi yüksek bir oranda saptamıştır. ${ }^{12}$ Zengin ve ark. yaptıkları çalışmada E.coli için 2009-2012 yıllarında siprofloksasin direnç oranını $\% 33$, Sağlam ve ark. \%32,80, Aktaş ve ark. \%37 olarak bildirmişlerdir. ${ }^{13-15}$ Aykan ve ark.'nın meta-analiz çalışmasında ise E. coli için siprofloksasin direncinin 1996-2001 yılları arasında \%12 iken 2008-2012 yılları arasında \%31 
Sakarya Tip Dergisi 2020;10(4):677-683

ÇİLBURUNOĞLU ve Ark., İdrar Kültürlerindeki Antimikrobiyal Duyarllıkları

\begin{tabular}{|c|c|c|c|c|c|c|c|c|c|c|c|c|c|c|c|}
\hline & AK & AMC & AMP & CRO & CİP & CT & F & GN & İMP & MEM & NOR & TZP & FEP & CAZ & SXT \\
\hline & $\mathrm{n}$ & $\mathrm{n}$ & $\mathrm{n}$ & $\mathrm{n}$ & $\mathrm{n}$ & $\mathrm{n}$ & $\mathrm{n}$ & $\mathrm{n}$ & $\mathrm{n}$ & $\mathrm{n}$ & $\mathrm{n}$ & $\mathrm{n}$ & $\mathrm{n}$ & $\mathrm{n}$ & $\mathrm{n}$ \\
\hline E.coli & $\begin{array}{c}132 \\
(0,61)\end{array}$ & $\begin{array}{c}1189 \\
(55,70)\end{array}$ & $\begin{array}{c}1295 \\
(75,80)\end{array}$ & $\begin{array}{c}1309 \\
(49,20)\end{array}$ & $\begin{array}{c}1311 \\
(37,60)\end{array}$ & $\begin{array}{c}1294 \\
(0,80)\end{array}$ & $\begin{array}{c}1271 \\
(4,20)\end{array}$ & $\begin{array}{l}1303 \\
(24)\end{array}$ & $\begin{array}{c}1314 \\
(1,60)\end{array}$ & $\begin{array}{c}1294 \\
(2,40)\end{array}$ & $\begin{array}{c}1268 \\
(44,20)\end{array}$ & $\begin{array}{l}1311 \\
(20)\end{array}$ & $\begin{array}{c}1296 \\
(42,30)\end{array}$ & $\begin{array}{l}1302 \\
(39)\end{array}$ & $\begin{array}{l}1312 \\
(49)\end{array}$ \\
\hline $\begin{array}{l}\text { Kleb- } \\
\text { siella } \\
\text { spp. }\end{array}$ & $\begin{array}{c}421 \\
(10,20)\end{array}$ & $\begin{array}{c}408 \\
(63,90)\end{array}$ & $\begin{array}{c}406 \\
(100)\end{array}$ & $\begin{array}{c}415 \\
(61,20)\end{array}$ & $\begin{array}{c}414 \\
(40,30)\end{array}$ & $\begin{array}{c}412 \\
(3,10)\end{array}$ & $\begin{array}{c}394 \\
(23,80)\end{array}$ & $\begin{array}{c}413 \\
(36,50)\end{array}$ & $\begin{array}{l}420 \\
(9)\end{array}$ & $\begin{array}{c}411 \\
(12,40)\end{array}$ & $\begin{array}{c}393 \\
(52,90)\end{array}$ & $\begin{array}{c}417 \\
(45,50)\end{array}$ & $\begin{array}{c}408 \\
(57,80)\end{array}$ & $\begin{array}{c}415 \\
(56,80)\end{array}$ & $\begin{array}{l}415 \\
(46)\end{array}$ \\
\hline Pseu- & $\begin{array}{c}81 \\
(8,60)\end{array}$ & - & - & - & $\begin{array}{c}81 \\
(18,50)\end{array}$ & $\begin{array}{c}78 \\
(5,10)\end{array}$ & - & $\begin{array}{c}82 \\
(15,90)\end{array}$ & $\begin{array}{c}80 \\
(18,80)\end{array}$ & $\begin{array}{c}80 \\
(15)\end{array}$ & - & $\begin{array}{c}80 \\
(26,30)\end{array}$ & $\begin{array}{c}79 \\
(25,30)\end{array}$ & $\begin{array}{c}78 \\
(20,50)\end{array}$ & - \\
\hline $\begin{array}{l}\text { En- } \\
\text { tero- } \\
\text { bacter } \\
\text { spp. }\end{array}$ & $\begin{array}{c}64 \\
(1,50)\end{array}$ & $\begin{array}{c}61 \\
(95)\end{array}$ & $\begin{array}{c}64 \\
(100)\end{array}$ & $\begin{array}{c}64 \\
(39)\end{array}$ & $\begin{array}{c}64 \\
(14)\end{array}$ & $\begin{array}{c}64 \\
(1,50)\end{array}$ & $\begin{array}{c}62 \\
(30,60)\end{array}$ & $\begin{array}{c}64 \\
(18,70)\end{array}$ & $\begin{array}{c}64 \\
(1,50)\end{array}$ & $\begin{array}{c}64 \\
(4,60)\end{array}$ & $\begin{array}{c}62 \\
(24,20)\end{array}$ & $\begin{array}{c}64 \\
(21,80)\end{array}$ & $\begin{array}{c}64 \\
(23,40)\end{array}$ & $\begin{array}{c}64 \\
(25)\end{array}$ & $\begin{array}{c}64 \\
(14)\end{array}$ \\
\hline $\begin{array}{l}\text { A.bau- } \\
\text { mannii }\end{array}$ & $\begin{array}{c}48 \\
(68,70)\end{array}$ & $\begin{array}{c}5 \\
(100) \\
\end{array}$ & $\begin{array}{c}3 \\
(100)\end{array}$ & $\begin{array}{c}3 \\
(100)\end{array}$ & $\begin{array}{c}46 \\
(80,40)\end{array}$ & $\begin{array}{c}46 \\
(2,10)\end{array}$ & - & $\begin{array}{c}47 \\
(82,90)\end{array}$ & $\begin{array}{c}46 \\
(80,40)\end{array}$ & $\begin{array}{c}48 \\
(77)\end{array}$ & - & $\begin{array}{c}5 \\
(80) \\
\end{array}$ & $\begin{array}{c}3 \\
(66,60)\end{array}$ & $\begin{array}{c}4 \\
(50)\end{array}$ & $\begin{array}{c}48 \\
(43,70)\end{array}$ \\
\hline $\begin{array}{l}\text { Pro- } \\
\text { teus } \\
\text { spp. }\end{array}$ & $\begin{array}{c}47 \\
(2,10)\end{array}$ & $\begin{array}{c}45 \\
(17,70)\end{array}$ & $\begin{array}{c}45 \\
(60)\end{array}$ & $\begin{array}{c}46 \\
(39,10)\end{array}$ & $\begin{array}{c}45 \\
(24,40)\end{array}$ & $\begin{array}{c}46 \\
(100)\end{array}$ & $\begin{array}{c}44 \\
(13,60)\end{array}$ & $\begin{array}{c}45 \\
(66,60)\end{array}$ & $\begin{array}{c}4 \\
(0)\end{array}$ & $\begin{array}{c}45 \\
(2,20)\end{array}$ & $\begin{array}{c}44 \\
(25)\end{array}$ & $\begin{array}{c}47 \\
(60,30)\end{array}$ & $\begin{array}{c}45 \\
(24,40)\end{array}$ & $\begin{array}{c}45 \\
(11,10)\end{array}$ & $\begin{array}{c}46 \\
(63)\end{array}$ \\
\hline $\begin{array}{l}\text { B. } \\
\text { cepha- } \\
\text { cia }\end{array}$ & - & - & - & - & - & - & - & - & - & - & - & - & - & - & $\begin{array}{l}22 \\
(0)\end{array}$ \\
\hline $\begin{array}{l}\text { Citro- } \\
\text { bacter } \\
\text { spp. }\end{array}$ & $\begin{array}{l}12 \\
(0)\end{array}$ & $\begin{array}{c}12 \\
(50)\end{array}$ & $\begin{array}{c}12 \\
(100)\end{array}$ & $\begin{array}{c}12 \\
(50)\end{array}$ & $\begin{array}{c}12 \\
(8,30)\end{array}$ & $\begin{array}{l}12 \\
(0)\end{array}$ & $\begin{array}{l}11 \\
(0)\end{array}$ & $\begin{array}{c}12 \\
(25)\end{array}$ & $\begin{array}{c}12 \\
(8,30)\end{array}$ & $\begin{array}{l}12 \\
(0)\end{array}$ & $\begin{array}{c}11 \\
(9,10)\end{array}$ & $\begin{array}{c}12 \\
(8,30)\end{array}$ & $\begin{array}{c}12 \\
(33,30)\end{array}$ & - & - \\
\hline $\begin{array}{l}\text { M. } \\
\text { mor- } \\
\text { ganii }\end{array}$ & $\begin{array}{l}11 \\
(0)\end{array}$ & $\begin{array}{c}11 \\
(100)\end{array}$ & $\begin{array}{c}11 \\
(100)\end{array}$ & $\begin{array}{l}11 \\
(0)\end{array}$ & $\begin{array}{c}11 \\
(36,30)\end{array}$ & $\begin{array}{c}11 \\
(100)\end{array}$ & $\begin{array}{c}11 \\
(100)\end{array}$ & $\begin{array}{c}11 \\
(63,40)\end{array}$ & $\begin{array}{l}11 \\
(0)\end{array}$ & $\begin{array}{l}11 \\
(0)\end{array}$ & $\begin{array}{c}11 \\
(63,60)\end{array}$ & $\begin{array}{l}11 \\
(0)\end{array}$ & $\begin{array}{l}11 \\
(0)\end{array}$ & $\begin{array}{l}11 \\
(0)\end{array}$ & $\begin{array}{c}11 \\
(45,40)\end{array}$ \\
\hline $\begin{array}{l}\text { S. } \\
\text { marc- } \\
\text { escens }\end{array}$ & $\begin{array}{c}7 \\
(0)\end{array}$ & $\begin{array}{c}7 \\
(100)\end{array}$ & $\begin{array}{c}7 \\
(100)\end{array}$ & $\begin{array}{c}7 \\
(14,30)\end{array}$ & $\begin{array}{c}7 \\
(14,30)\end{array}$ & $\begin{array}{c}7 \\
(100)\end{array}$ & $\begin{array}{c}7 \\
(0)\end{array}$ & $\begin{array}{c}7 \\
(14,30)\end{array}$ & $\begin{array}{c}7 \\
(0)\end{array}$ & $\begin{array}{c}7 \\
(0)\end{array}$ & $\begin{array}{c}7 \\
(42,90)\end{array}$ & $\begin{array}{c}7 \\
(0)\end{array}$ & $\begin{array}{c}7 \\
(14,30)\end{array}$ & $\begin{array}{c}7 \\
(14,30)\end{array}$ & $\begin{array}{c}7 \\
(0)\end{array}$ \\
\hline
\end{tabular}

Tablo 3. Gram pozitif bakterilerin antibiyotik direnç oranları

\begin{tabular}{|c|c|c|c|c|c|c|c|c|c|c|c|c|}
\hline & AMP & CİP & $\mathrm{E}$ & DA & VA & TEC & LZD & SXT & S300 & & $\mathrm{P}$ & $\mathrm{OX}$ \\
\hline & $\mathrm{n}(\%)$ & n (\%) & n (\%) & $\mathrm{n}(\%)$ & $\mathrm{n}(\%)$ & n (\%) & n (\%) & $\mathrm{n}(\%)$ & n (\%) & n (\%) & n (\%) & n (\%) \\
\hline E. feacalis & $\begin{array}{c}164 \\
(1,80)\end{array}$ & $\begin{array}{c}159 \\
(32,70)\end{array}$ & - & - & $\begin{array}{c}163 \\
(1,80)\end{array}$ & $\begin{array}{c}164 \\
(1,80)\end{array}$ & $\begin{array}{c}164 \\
(1,20)\end{array}$ & $\begin{array}{c}163 \\
(100)\end{array}$ & $\begin{array}{c}164 \\
(41,50)\end{array}$ & $\begin{array}{c}164 \\
(23,10)\end{array}$ & - & - \\
\hline E. faecium & $\begin{array}{c}114 \\
(93,90) \\
\end{array}$ & $\begin{array}{c}111 \\
(85,60) \\
\end{array}$ & - & - & $\begin{array}{c}114 \\
(16,70) \\
\end{array}$ & $\begin{array}{c}115 \\
(19,10) \\
\end{array}$ & $\begin{array}{c}114 \\
(2,60) \\
\end{array}$ & $\begin{array}{c}115 \\
(100) \\
\end{array}$ & $\begin{array}{c}114 \\
(72,80) \\
\end{array}$ & $\begin{array}{c}112 \\
(52,70) \\
\end{array}$ & - & - \\
\hline S. agalactiae & - & - & $\begin{array}{c}51 \\
(47)\end{array}$ & $\begin{array}{c}38 \\
(21)\end{array}$ & $\begin{array}{c}58 \\
(1,70)\end{array}$ & $\begin{array}{l}59 \\
(3)\end{array}$ & $\begin{array}{l}63 \\
(0)\end{array}$ & $\begin{array}{c}20 \\
(80)\end{array}$ & - & $\begin{array}{l}42 \\
(0)\end{array}$ & $\begin{array}{l}67 \\
(0)\end{array}$ & \\
\hline S. aureus & $\begin{array}{c}16 \\
(100)\end{array}$ & $\begin{array}{l}27 \\
(0)\end{array}$ & $\begin{array}{c}26 \\
(26,90)\end{array}$ & $\begin{array}{c}28 \\
(21,40)\end{array}$ & $\begin{array}{l}28 \\
(0)\end{array}$ & $\begin{array}{c}26 \\
(7,70)\end{array}$ & $\begin{array}{c}28 \\
(3,60)\end{array}$ & $\begin{array}{l}23 \\
(0)\end{array}$ & - & - & $\begin{array}{c}25 \\
9(6)\end{array}$ & $\begin{array}{c}27 \\
(51,90)\end{array}$ \\
\hline
\end{tabular}

AMP: Ampisilin, CIP: Siprofloksasin, E: Eritromisin, DA: Klindamisin, VA: Vankomisin, TEC: Teikoplanin, LZD: Linezolid, SXT: Trimetoprim-Sulfametoksazol, S300: Yüksek düzey Streptomisin, GN120: Yüksek düzey Gentamisin, P: Penisilin, OX: Oksasilin

oranına yükseldiği belirtilmiştir. ${ }^{16}$ Aytaç ve ark. yaptıkları çalışmada Ocak 2010-Haziran 2014 tarihleri arasında E. coli için siprofloksasin direncinde bir artış olduğunu görmüş ve siprofloksasin direncini \%24,60 olarak tespit etmişlerdir. ${ }^{17}$ Bizim çalışmamızda siprofloksasin direnci \%37,60 olarak saptandı. Tüm veriler E. coli suşlarında artan bir siprofloksasin direncini göstermektedir ve her merkezin antibiyotik direnç oranları değişmektedir.

Dağlar ve ark. E. coli için en etkili antibiyotikleri karba- 
penemler (\%100) ve amikasin (\%97.60) olarak bulmuşlardır.18 Yılmaz ve ark. yaptıkları çalışmada E. coli için en etkili antibiyotikleri karbapenemler $(\% 96,40-98,90)$ ve amikasin $(\% 94,60)$ olarak tespit etmişlerdir.19 Ece Terek ve ark. yaptıkları çalışmada E. coli’ ye karşı en yüksek duyarlılık oranlarını karbapenemlere (\%100) ve amikasine $(\% 88,90)$ karşı bulmuşlardır. ${ }^{20}$ Çalışmamızda da E. coli için en düşük direnç oranı amikasinde \%0.6, imipenemde $\% 1,60$ ve meropenemde $\% 2,40$ olarak bulundu. Bu nedenle bahsi geçen bu antibiyotiklerin son seçenek tedavi olarak kullanılması gerektiği ve artan direnç oranlarından dolayı uygunsuz kullanımlarından kaçınılması gerektiği düşünülmektedir.

Demirtürk ve ark. yaptıkları çalışmada E. coli'de en az duyarlılık oranlarının \%16,60 ile ampisilinde ve \%28,40 ile trimetoprim-sulfametoksazolde olduğunu tespit etmişlerdir. ${ }^{21}$ Ece Terek ve ark. E. coli'ye karşı en az duyarlılık oranlarının \%34,20 ile ampisilin ve \%51 ile trimetoprim-sulfametoksazolda olduğunu bulmuşlardır. ${ }^{20}$ Dağlar ve ark. E. coli suşlarında ampisiline karşı \%58,50, trimetoprim-sulfametoksazole karşı \%39,50 oranında direnç oranlarını bulmuşlardır. ${ }^{18}$ Çalışmamızda ampisilin direnci oranı \%75,80 olarak diğer çalışmalara kıyasla daha yüksek bulundu. Trimetoprim-sulfametoksazol direnç oranı ise \%49 olarak diğer çalışmalarla benzer biçimde bulundu.

Klebsiella spp., birçok çalışmada İYE’lerde E. coliden sonra ikinci sıklıkta izole edilmekte ve genellikle antibiyotik direnç oranları E. coli’ye göre daha yüksek olarak bildirilmektedir. ${ }^{22,23}$ Temiz ve ark. Klebsiella spp. için en etkili antimikrobiyalleri imipenem ve amikasin olarak bulmuştur. ${ }^{24}$ Ece Terek ve ark. yaptıkları çalışmada K. pneumoniae için amikasin, imipenem ve meropenem antibiyotik duyarlılık oranlarını sırasıyla \%98, \%100 ve \%100 olarak bulmuşlardır. ${ }^{20}$ Terzi ve ark. elde ettikleri verilere göre Klebsiella spp. için en etkili antibiyotiğin \%99 duyarlılık oranıyla amikasin olduğunu tespit etmişlerdir. Suşların tümündeki karbapenem direnç oranını ise \%9 olarak belirtmişlerdir. ${ }^{25}$ Çalışmamızda Klebsiella spp. için en etkili antibiyotiklerin imipenem (\%9), amikasin $(\% 10,20)$ ve meropenem $(\% 12,40)$ olduğu bulundu. Albayrak ve ark. Klebsiella spp. izolatlarında direnç oranlarını amoksisilin-klavulonat için \%56; trimetoprim-sulfametoksazol için $\% 30,70$; siprofloksasin için \%5,50 olarak tespit etmişlerdir. ${ }^{26}$ Çalışmamızdaki Klebsiella spp. izolatlarında direnç oranları ise amoksisilin-klavulonat için \%63,90; trimetoprim-sulfametoksazol için \%46; siprofloksasin için \%40,30 olarak daha yüksek oranlarda tespit edildi.

Üriner sistem enfeksiyonları enterokokların yol açtı̆̆ 1 klinik hastalıkların en sık görülen tipidir ve klinik mikrobiyoloji laboratuvarında izole edilen enterokokların en sık kaynağı idrar kültürleridir. ${ }^{27}$ Gram pozitif bakteri enfeksiyonlarının tedavisinde kullanılan birçok antimikrobiyal ajana karşı artan direnç enterokok türleri için dikkat çeken bir özelliktir. ${ }^{28}$ Gülcan ve ark. yaptıkları çalışmalarında E. faecalis ve E. faecium için direnç oranlarını sırasıyla ampisilin için \% 6,5 ve \% 91,70; siprofloksasin için \% 55,40 ve $\% 76,90$ olarak tespit etmiş olup yüksek düzey streptomisin direncini \% 55,9 ve \% 86,7; yüksek düzey gentamisin direncini \% 36,70 ve \% 53,30 olarak bulmuşlardır. Buna karşılık vankomisin ve teikoplanin direnci tespit etmemişlerdir. ${ }^{29}$ Çalışmamızda izole edilen. E. faecalis ve E. faecium için direnç oranları sırasıyla, ampisilin için \%1,80 ve $\% 93,90$; siprofloksasin için \%32,70 ve $\% 85,60$ olup yüksek düzey streptomisin direnci $\% 41,50$ ve $\% 72,80$; yüksek düzey gentamisin direnci $\% 23,10$ ve $\% 52,70$ olarak saptand. Vankomisin için sırasıyla \%1,80 ve \%16,70; teikoplanin için ise \%1,80 ve \%19,10 oranında direnç olduğu tespit edildi. Bu verilere göre antibiyotik direnç oranları E. faecalis'de E. faecium'a kıyasla daha düşüktür. Bu yüzden izole edilecek enterokokların tür düzeyinde adlandırılması ve antibiyotik duyarlılığının belirlenmesi E. faecalis türleri arasında direncin artmaması açısından yararlı olabilir.

İdrar yolu enfeksiyon etkenlerinin antibiyotik direnç oranları merkezlere göre değişiklik göstermektedir. Bu yüzden her merkez kendi bölgesindeki enfeksiyon etkeni izolatların dağılımını ve antibiyotik direnç profilini belirlemeli 
ve tedavi protokollerini bu sonuçlara göre düzenlemeli ve yayınlamalıdır.

Çalışmanın etik kurul onayı, Sakarya Üniversitesi bünyesinde yer alan Girişimsel Olmayan Klinik Araştırmalar Etik Kurul'dan (04.09.2020 tarih ve $71522473 / 050.01 .04 / 476$ sayılı) alınmıştır. 
Sakarya Tip Dergisi 2020;10(4):677-683

ÇİLBURUNOĞLU ve Ark., İdrar Kültürlerindeki Antimikrobiyal Duyarllıkları

\section{Kaynaklar}

1. Kandemir Ö, Ŭ̆uz M, Taşdelen B. Hastane kökenli üropatojen Escherichia Coli suşlarının ampirik tedavisinde sık kullanılan antibiyotiklere yıllar içinde gelişen direnç oranlarındaki değișim. FLORA 2009;14(4):170-174.

2. Tekin A, Deveci Ö, Dal T, Tekin R, Özekinci T, Dayan S. Ayaktan ve yatan hastalarda izole edilen mikroorganizmalarn antibiyotiklerin in vitro etkinliği, ANKEM Derg 2012;26(2):618. http://dx.doi.org/10.5222/ankem.2012.061

3. Alpay Y, Yavuz MT, Aslan T, Büyükzengin B. Genișlemiș Spektrumlu Beta-Laktamaz Pozitif Escherichia Coli ile oluşan komplike olmayan üriner sistem infeksiyonlarmin tedavisinde oral antibiyotikler Karbapenemlere alternatif olabilir mi? ANKEM Derg 2017;31(3):85-91.

4. Duran H, Çeken N, Kula Atik T. İdrar kültüründen izole edilen Escherichia coli ve Klebsiella pneumoniae suşlarının antibiyotik direnç oranları: Dört yıllık analiz. ANKEM Derg. 2020;34(2):41-7.

5. Russell DB. Roth NJ. Urinary tract infections in men in a primary care population. Aust Fam Physicians 2001; 30:177-9. PMid:11280121

6. Sobel JD, Kaye D. Urinary tract infections. In: Mandell GL, Bennett JE, Dolin Reds. Principles and Practice of Infectious Diseases. New York: Churcill Livingstone, 2000:773.

7. Kolayl F. Uriner sistem enfeksiyonlarında etken patogenez ve mikrobiyolojik tanı. Turkiye Klinikleri J Urology-Special Topics. 2010;3(3):8-18.

8. Guidelines on urological infections. European Association of Urology 2014. Internet adresi: http://www.uroweb.org/gls/pdf/19\%20Urological\%20infections_LR.pdf. Erişim tarihi: 29.05.2014

9. Akata F. Uriner sistem infeksiyonlarında uygun antibiyotik kullanımı. Klinik Dergisi 2001; 14: 114-123

10. Gupta K, Hooton TM, Naber KG, Wullt B, Colgan R, Miller LG, et al. International clinical practice guidelines for the treatment of acute uncomplicated cystitis and pyelonephritis in women: A 2010 update by the Infectious Diseases Society of America and the European Society for Microbiology and Infectious Diseases. Clin Infect Dis 2011; 52(5): 103-20.

11. Duman Y, Bozkurt İ, Tekerekoğlu MS. Investigation of Antibiotic Resistance and ESBLPresence of Community-Acquired Escherichia coli Strains, Isolated from UTI in Afșin State Hospital. Med Sci, 2014; 3(3): 1408-18.

12. Saraçoğlu KT, Fidan V, Pekel Ö, Saraçoğlu A, Kalkandelen S, Arpalı E. İdrar kültürlerinde izole edilen bakterilerin antibiyotik duyarllikları. J Clin Exp Invest 2013; 4(3): 356-359.

13. Zengin K, Tanık S, Albayrak S, Kaba M, Pirinççi N. Van Bölgesindeki üriner sistem enfeksiyon etkenleri ve antibiyotik duyarllikları. Bozok Tip Derg 2014; 4(1); 1-5.

14. Sağlam H.S, Öğütlü A, Demiray V, Karabay O. Uriner enfeksiyonlarda toplum kökenli Escherichia colinin yeri ve gelișen antibiyotik direnci. Nobel Medicus 2012; 8(1): 67-8.

15. Aktaş SÇ, Gençer S, Batırel A, Hacıseyitoğlu D, Özer S. CLSI ve EUCAST Önerilerine Göre Genişlemiş Spektrumlu Beta-Laktamaz Üreten Escherichia coli İdrar İzolatlarında Fosfomisin Duyarlliğı. Mikrobiyol Bul 2014; 48(4): 545-55.
16. Aykan ȘB, Çiftci IHH. Türkiye’de idrar kültürlerinden izole edilen Escherichia coli suşlarinin antibiyotiklere direnç durumu: bir meta-analiz. Mikrobiyol Bul 2013; 47(4): 603-8.

17. Aytaç Ö, Mumcuoğlu İ, Çetin F, Aksoy A, Aksu N. Erişkin hastalarda toplum kaynaklı üriner sistem enfeksiyonlarından izole edilen Escherichia coli suşlarının antibiyotik duyarl liklarının yıllara göre değişimi (2010-2014). Turk Hij Den Biyol Derg 2015; 72(4): 273-80.

18. Dağlar D, Demirbakan H, Yildırım Ç, Öztüek F, Özcan A, Sipen N et al. İdrar örneklerinden izole edilen bakteriler ve antibiyotiklere duyarlllkları. Türk Mikrobiyol Cem Derg 2005(3);35:189-94.

19. Yllmaz E, Özakın C, Sinırtaș M, Gedikoğlu S. Uludă̆ Universitesi Tip Fakültesi Bakteriyoloji Laboratuvarında 1999-2002 yılları arasında idrar örneklerinden izole edilen mikro organizmalar ve antibiyotik duyarlliklari. Infeksiyon Dergisi 2005; 19(1):91-6.

20. Ece Terek G, Tunçel Başoğlu M. Bir üniversite hastanesine gönderilen idrar kültürlerinde üreyen izolatların dağılımı ve antimikrobiyal duyarllık profilinin incelenmesi. Ege Tip Dergisi / Ege Journal of Medicine 2013;52(3):136-140

21. Demirtürk N, Demirdal T, EldemirT, İnce R, Altındiș M. İdrar örneklerinden izole edilen bakterilerin antibiyotiklere duyarlhlkları. Türk Mikrobiyol Cem Derg 2005;35(2):275-8

22. Dündar D, Willke A, Sönmez T.G. İdrar yolu infeksiyonu etkenleri ve antibiyotik duyarllikları. Klimik Derg 2008; 21: 7-11

23. Pullukçu H, Taşbakan M, Aydemir \$̧ve ark. İdrar kültürlerinden soyutlanan bakteriler ve çeșitli antibiyotiklere in-vitro duyarlliklarının değerlendirilmesi, Ankem Derg 2006; 20:26-30.

24. Temiz H, Özbek E, Vural DG, Özekinci T. Klebsiella İzolatlarının Antimikrobiyal Direnç Oranlarının Değerlendirilmesi. Türk Mikrobiyol Cem Derg 2015;45:68-74.

25. Terzi HA, Karakeçe E, Çiftci İH. Klebsiella spp. izolatlarının antibiyotik duyarlllkklarının değerlendirmesi. ACU Sağlık Bil 2013;4:68-71.

26. Albayrak N, Kaya Ş. Çeșitli klinik örneklerden izole edilen Escherichia coli ve Klebsiella pneumoniae suşlarının genişlemişs spektrumlu beta laktamaz üretimleri ve antibiyotik direnç oranlart. Türk Mikrobiyol Cem Derg 2009; 39: 16-21

27. Yilderım M. Enterokoklar ve enterokoklarla gelișen infeksiyonlar. Düzce Tip Dergisi 2007; 2:46-52.

28. Yamazhan T. Vankomisine dirençli enterokoklar. Direncin önlenmesi ve kontrol. 2. EKMUD Bilimsel Platformu Kitabı, 11-14 Mart 2009, Antalya: 49-52.

29. Gülcan A, Aslantürk A, Gülcan E. İdrar kültürlerinden izole edilen mikroorganizmalar ve in vitro antibiyotik duyarlllk durumları. Abant Tip Derg 2012; 1(3): 61-7. 